\title{
Anatomical, Histological And Histochemical Studies On Some Organs Of True Desert Rodents In The Egyptian Habitats
}

\author{
Boshra A. El- Salkh*, Zaki T. Zaki ${ }^{* *}$ Mohammad I. Basuony ${ }^{* *}$ \\ and Hanaa A. Khidr* \\ Department of Zoology, Faculty of Science, Al-Azhar University \\ for Girls ${ }^{(1)}$ and Boys ${ }^{(2)}$
}

\begin{abstract}
Aim of the work: The present study aimed to compare between the anatomy, histology and histochemistry of two species belonging to two different families namely Muridae and Dipodidae. Muridae is the largest family of rodents in the world; it is represented in this work by fat sand rat Psammomys obesus. Four-toed jerboa Allactaga tetradactyla represents the other family, Dipodidae. Psammomys obesus lives in coastal presaharan region; the preferred habitat is saline marshes and wadis where halophytic plants were abundant. However, Allactaga tetradactyla, inhabites the salt marshes and clay desert areas of coastal plains.

Material and methods: The investigated animals were collected from desert, weighed and transferred alive to the laboratory in separate cages then anaesthetized with ether, after which they were carefully dissected, organs are taken out and prepared for the histological and histochemical studies.

The nucleocytoplasmic index of liver cells was calculated, kidney weighed and the relative thickness of cortex, outer and inner medulla was measured and total glomerular number was recorded.

Results: The liver, as in mammalian species, is consists of five separate lobes. The mitotic index of Psammomys obesus is smaller than that found in Allactaga tetradactyla. This may be due to the increased activity of Allactaga tetradactyla.

In the kidney, the cortex is classified into three regions namely superficial, midcortical and juxtamedullary zones. Both number and diameter of glomeruli, glomerular volume and relative glomerular blood volume is greater in Psammomys obesus than that in Allactaga tetradactyla.

Conclusion: These observations indicate the ability of Psammomys obesus to produce highly concentrated urine than that of Allactaga tetradactyla.
\end{abstract}

Key words: Desert Rodents, Histochemical, Liver, Kidney

\section{Introduction}

Fat sand rat Psammomys obesus lives in the coastal and presaharan regions. They preferred the habitats of salt marshes and wadis where halophytic plants are abundant (Zaime and Guatier, 1989 and Degan 1993). They build a network of shallow burrows and because they are frequently diurnal, they may be seen to feeding on halophytic plants. This kind of activity is only possible provided sand rats possess special mechanisms for staying cool, or for obtaining water which may be used for evaporative cooling. The key to their success seems to be their ability to eat the succulent leaves of halophytic plants and then eliminate the excess salts in a more concentrated urine. Measurements of this urine show it is up to four times as salty as sea water (Happold, 1984)

The previous author added that, the higher costant relative humidity of the burrows reduces water evaporation loss, where at night, burrow temperature are warmer than outside.

Fat sand rat Psammomys obesus is normally normoglycemic when eating desert vegetation but when allowed free access to standard laboratory foods show obesity, hyperinsulinemia, hyperglycemia and occasionally ketoacidosis (Marquie et al., 1984).

Four-toed jerboa Allactaga tetradactyla is restricted in coastal areas in Egypt he portal veins, hepatic artery, bile duct and 
also a lymphatic vessel lying in a small amount of connective tissue such as in Meriones hurrianae and tatera indica (Purohit and Ghosh, 1963).

A. tetradactyla feeds primary on seeds and succulent vegetation especially plants with milky juices, but it also has been known to feeds on insects. It does not drink water at all, but instead lives on metabolic water produced by the chemical breakdown of food (MacDonald, 1984). A. tetradactyla has been beneficial for controlling crops by preying on insects; jerboas keep the post population low so the effect of insect predation on crop is reduced.

Basal metabolic rate of $A$. tetradactyla is $68 \%$ less than that of white rat feeds (Hendrickson,1983). Atemperature increase of $40^{\circ} \mathrm{C}$ kills white rats but only cause sleeping jerboas to salivate. The life span of A. tetradactyla is less than two years. Also, the known geological range of the dipodids is Pleistocene to Recent in North Africa (Nowak, 1991; Wilson and Reeder, 2005), suggesting that A. tetradactyla is a fairly recent species on the geological time scale.

The liver is a dark red or reddish brown, the colour caused by a very rich blood supply. The hepatic lobule is a polygonal with a central vein and portal peripheral canals at the corners. The liver tissue is divided into lobules each of which is surrounded by a connective tissue sheath containing of elastic fibers (Lesson et al., 1988). Hepatic cells are polygonal and the nuclei are spherical or ovoid with a regular surface and show considerable variation in size from cell to cell. Each nucleus is vesicular in type with prominent scattered chromatin granules and one or more nucleoli (Novikoff and Essner, 1960). At the surface adjacent to a sinusoidal space, the hepatic cell is separated from the wall of vascular channel by a narrow perisinusoidal space, at this surface; the plasma membrane of the hepatic cell is covered by numerous long microvilli (Lesson et al., 1988).

The portal area comprise branches of the portal veins, hepatic artery, bile duct and also a lymphatic vessel lying in a small amount of connective tissue such as in Meriones hurrianae and tatera indica (Purohit and Ghosh, 1963).

According to Lesson et al. (1988) and Zaki et al. (1994), the kidney of the mammalian species had been typical beanshaped appearance characteristic of the unipolar mammalian kidneys. The kidney consists of superficial capsule, outer cortex and inner medulla. The outer cortex is highly vascular; the inner medulla is slightly thick and less vascular. Both cortex and medulla are built up of different tubule structures (El-Naggar, 1989).

The nephron is the functional unit of the kidney; each nephron consists of corpuscle, proximal convoluted tubules, loop of Henle, distal convoluted tubules and collecting tubules. Bowman's capsule is formed of two thin cellular layers, an inner visceral layer and an outer parietal one, which is a simple squamous epithelium resting on basal lamina (Safer et al., 1990). The visceral layer is formed of flattened epithelium (Zaki, 1993).

The loop of Henle consists of two limbs, thick ascending and thin descending limbs. The descending limb extends into the inner medulla but the thick ascending limb extends only in the outer medulla (Kaissling et al., 1975).

Hickman et al. (1984) stated that the varying ability of different mammals to form concentrated urine is closely related with the length of the loop of Henle. They showed that the bear which has no need to conserve water in its aquatic habitat, has short loops and can concentrate its urine to only approximately twice that of the blood plasma of humans, with relatively longer loops which concentrate urine 4.2 times that of the blood plasma. Desert animals have much greater urinoconcentrating power, the camel can produce urine 8 times as the plasma concentration, the gerbil 14 times and generally all mammals can produce concentrated urine by means of a counter current multiplier system localized in the loop of Henle. In the fennec fox Vulpes $z e r d a$, the daily urine production is considerably reduced mounting to only $59 \%$ of the expected level (Younis, 2008 and Basuony et al., 2009).

The kidney of the jerboa is unipolar one, similar to that of other small rodents but with characteristically very long papilla in the desert rodents (Basuony, 1993). However, other mammalian species such as bats have short papillae (Zaki et al., 1994). Histochemically, the basement membrane 
of the renal structure as well as, the brush border of the proximal convoluted tubules epithelium are PAS positive (Lesson et al., 1988 and Basuony, 1993), also the glomerular cells are PAS positive (Foster and Riad, 1963).

\section{Material and Methods}

The investigated animals include two desert rodents belonging to two different families. Muridae is the largest family of rodents in the world; this family is represented in this work by fat sand rat Psammomys obesus. Four-toed jerboa Allactaga tetradactyla represents the family called Dipodidae. According to Osborn and Helmy (1980), Psammomys obesus has three subspecies, the first subonecies namely obesus was collected from Western Desert, the second subspecies terraesanctae from north Sinai and the third one nicoli from Eastern Desert. The second species, Four-toed Jerboa Allactaga tetradactyla, was collected from Mersa Matrouh (coastal belt of the Western Desert). The specimens were weighed and transferred alive to the laboratory in separate cages.

For gross anatomy, the species were anaesthetized with ether, after which they were carefully dissected and examined. Anatomy of each rodent includes liver kidneys. The liver was weighed in order to calculate the hepatosomatic index (HSI)

HSI $=$ Weight of liver in grams $\mathrm{x} 100$ / Weight of animal in grams.

For histological studies, other specimens of each studied species were anaesthetized, quickly dissected and the organs previously mentioned were taken out and washed in physiological saline solution $(0.9 \%)$. After which the required organs were fixed in Bouin's solution for about 24 hours. Small pieces of each studied organs were then preserved in $70 \%$ ethyl alcohol, dehydrated in graded series of alcohol, cleared in xylene and embedded in paraffin wax as usual. Sections of 4-6 $\mu$ thickness were mounted on clean glass slides and stained with Harris haematoxylin and Eosin $(\mathrm{Hx} \& \mathrm{E})$ for general structure and Mallory trichrome stain for connective tissue (Pearse, 1968).

For quantitative study we measured at least the diameter of one hundred liver cells (in more than one direction) of each nucleus and cell, then the volume of nuclei and cells were calculated as sphere. The nucleocytoplasmic index (NP) was calculated according to the equation of El-Banhawy et al. (1972):

$$
\mathrm{NP}=\mathrm{VN} / \mathrm{VC}-\mathrm{VN}
$$

Where $\mathrm{VN}$ is the volume of the nucleus and VC is the volume of the cell. For histochemical studies, Periodic acid Schiff's reagent (PAS) was applied to demonstrate the carbohydrates (Mc Manus, 1946).

After dissection, the kidneys of each sacrifices animal was sectioned longitudenally and placed in Bouin's fixative for histological purposes. The other kidney weighed and one half of this kidney was postfixed for five minute in $10 \%$ formalin (Altaschuler et al., 1979). The relative thickness of cortex, outer and inner medulla of the kidney was measured using calibrated eye piece on a dissecting microscope. The total number of glomeruli in a mid-sagital longitudinal section was also estimated. According to Altaschuler et al. (1979), these measurements were factorized by kidney weight because of the variation in animal size. The ratio of medulla to cortical thickness is one indicator of the species urine concentrating capacity (Munkacsi and Palkovits, 1965). The relative glomerular blood volume (RGBV) was calculated according to method of Palkovits and Zolani (1963) using the formula:

$$
\mathrm{V}=\mathrm{T} / 6(\mathrm{LB})^{3 / 2}
$$

Where $\mathrm{V}$ is the glomerular volume, $\mathrm{T}$ is a constant equal to $3.14, \mathrm{~L}$ is the long glomerular axis and $\mathrm{B}$ is the short glomerular axis.

RGBV $=\mathrm{VXN}$
$\begin{aligned} & \text { Where, } \mathrm{N} \text { is the average number of } \\ & \text { glomeruli. }\end{aligned}$

\section{Results}

\section{Anatomical observations}

\section{1- The liver}

The liver of the two studied rodents consists of five separated lobes, right and left central lobes, left lateral lobe, caudate and Spigelian lobes. The left lobe is the largest, the right central lobe is larger than the left, and the Spigelian lobe is smaller 
than the caudate lobe. The investigated species had gall bladder which lies in a depression in the right central lobe of the liver.

\section{2- The kidneys}

The kidney of the studied rodents is bean like structure, lying behind the peritoneum in the posterior region of the upper abdomen, one kidney on each side of the upper lumbar vertebra. Each kidney is enclosed by a fibroconnective tissue capsule. It is characterised by one long papilla, so, the investigated rodents are called unipolar mammalian kidney. The body weight in Psammomys obesus is about $133.6 \pm 29.1 \mathrm{~g}$ which is greater than the body weight in Allactaga tetradactyla that weighed $48.3 \pm 9.01 \mathrm{~g}$. The kidney weight in Psammomys obesus is about $0.93 \mathrm{~g}$ and that of Allactaga tetradactyla weighted about $0.29 \mathrm{~g}$. The ratio of kidney weight to body weight in Psammomys obesus is about 0.83 and in Allactaga tetradactyla is about 0.60 (Table 1).

The cross section of kidney showed two anatomical distinct regions, the outer cortex and inner medulla, both terminate by renal papilla. The renal cortex is reddish brown in colour and varied in thickness from $3.3 \mathrm{~mm}$ in Psammomys obesus to 1.8 $\mathrm{mm}$ in Allactaga tetradactyla. It was found that the ratio of the renal cortical thickness to the kidney weight (in $\mathrm{g}$ ) is equal to 3.3 and $1.8 \mathrm{~mm} / \mathrm{g}$ in Psammomys obesus and Allactaga tetradactyla respectively (Table 1).

The medulla is divided into outer and inner subregions. The thickness of the outer medulla in Psammomys obesus is about 1.5 $\mathrm{mm}$ while in Allactaga tetradactyla is about $1.9 \mathrm{~mm}$. Striking difference appeared when the thickness of the outer medulla is factorized by the kidney weight (in g). For each species, the average ratio of Psammomys obesus is $1.61 \mathrm{~mm} / \mathrm{g}$ and 3.1 $\mathrm{mm} / \mathrm{g}$ in Allactaga tetradactyla. The inner medulla was recognized by external portion of papilla. The mean length is about $6.8 \mathrm{~mm}$ and $3.4 \mathrm{~mm}$ in Psammomys obesus and Allactaga tetradactyla respectively (Table $1)$.

The percentage of length of the inner medulla when compared to the whole medulla is 79.6 in Psammomys obesus and
64.1 in Allactaga tetradactyla (Table 2). The ratio of medullary thickness to cortical thickness is about $5.59 \%$ in Psammomys obesus and $2.9 \%$ in Allactaga tetradactyla (Table 2).

\section{Histological observations \\ 1- The liver}

The liver is a compound tubular gland covered by a thin peritoneal epithelium formed of flattened cells resting on basement membrane of fibroconnective tissue composed of collagenous fibers with relatively few cells most of which are fibroblasts. Each lobe is subdivided by connective tissue into polyhedral lobules and the interlobular connective tissue is restricted to the portal canal at the angle of the lobules.

In Psammomys obesus, the hepatic lobule is prismatic in shape with a central vein forming its central axis. It is built up of columns of hepatic cells, hepatocytes, which radially arranged from the central vein to the periphery of the lobule (Fig. 1). The hepatocytes are polygonal in shape, each cell possesses a distinct limiting membrane and a clump of basophilic material to give a slightly basophilic cytoplasm (Fig. 2). The mean of hepatosomatic index of Psammomys obesus is about $4.10 \pm 1.33$. Nuclei of hepatocytes are spherical or ovoid with regular surface and show a considerable variation in size from cell to cell. The mean nucleocytoplasmic index of hepatocytes of Psammomys obesus is measured about $56.37 \pm 20.69 \mu$ while the mitotic index is measured about $68.28 \pm$ $10.23 \mu$ (Table 3). Binucleated cells are present; each nucleus has prominent scattered chromatin granules with one or more nucleoli and stain less intensely than nuclei of other cells in the liver. The columns of hepatocytes are separated by blood sinusoids which take the same radial direction as the hepatocytes. Blood sinusoides are scattered between the hepatocytes, so that, their walls are formed by the hepatocytes (Fig. 3).

Outside the lobules, at certain angle lie portal islands of connective tissue, each contains a branch of hepatic artery, portal vein and bile duct with lymphatic vessels. The largest structure usually is the branch of hepatic portal vein. The smallest in size 
is the artery; the hepatic artery and bile ducts are intermediate in size and are lined by cuboidal epithelial cells.

Sinusoidal spaces differ from capillaries by increased diameter. Two main types of cells with intermediate forms, are present in the sinusoidal lining of the liver. The first type is the endothelial cell which is small, elongated, darkly stained nucleus and greatly attenuated cytoplasm. The second type is kupffer cell which has relatively large oval nuclei with cytoplasmic arms (Fig. 3).

Histochemically, the liver gives PAS positive reaction due to the secretion of neutral mucosubstance (Fig. 4).

In Allactaga tetradactyla, the structure of liver is similar to that in Psammomys obesus except slight differences. The lobulation of liver cells are less distinct from the central vein than of Psammomys obesus, so that, the column of hepatocytes is polygonal in shape as in Psammomys obesus with distinct membrane (Fig. 5). Nuclei are rounded, strongly basophilic and the cytoplasm is eosinophilic. Binucleated cells are present (Fig. 6).

The mean of hapatosomatic index of Allactaga tetradactyla is about $5.27 \pm 0.83$ which is larger than that in Psammomys obesus.

The mean nucleocytoplasmic index of hepatocytes of Allactga tetradactyla is measured about $75.34 \pm 31.25 \mu$ which is greater than that of Psammomys obesus and the mean of mitotic index is measured about $45.85 \pm 19.21 \mu$ that lesser than that in Psammomys obesus (Table 3).

The portal space is very similar to that of Psammomys obesus which contains a branch of hepatic artery, portal vein and bile ducts with a lymphatic vessels. The largest structure usually is a branch of the portal vein, the smallest structure is the hepatic artery and the bile duct is intermediate in size and its lining is of cuboidal epithelium. The sinusoidal space as in Psammomys obesus contains two types of cells, the first type is endothelial cell and the second types Kupffer cell (Fig. 7). For mucosubstance study, the cytoplasm gave PAS positive reaction.

\section{2- The kidneys}

In Psammomys obesus, the kidney is enveloped by a capsule formed of thin fibroconnective tissue. The kidneys consist of an outer region, cortex, and an inner medulla which extends to the ureter by renal papilla. The kidney is a compound tubular gland formed of large number of urineferous tubules; each urineferous tubule consists of a large number of nephric units and collecting tubules. The nephric unit is formed of different structures forming several segments. Malpighian corpuscle, the first segment is composed of glomerulus and Bowman's capsule, the proximal convoluted tubules, loop of Henle and distal convoluted tubules (Figs. 8-9).

The renal (Malpighian) corpuscle is a spherical structure formed of glomerulus which is enclosed by Bowman's capsule. The Bowman's capsule is formed of two thin cellular layers, an outer parietal layer and an inner visceral layer. The parietal one enclosing a narrow space, the urinary space, which is continuous with the lumen of the proximal convoluted tubules. The second layer, the visceral layer, is formed of flattened squamous epithelial cells. The visceral layer is a closely nests glomerular capillaries, but the cells are greatly modified and do not form a complete sheet, these cells are called podocytes.

The cortex is composed of several layers of glomeruli which are closely arranged (Fig. 8). This is due to the thickness of the cortex that measured 1.20 $\mathrm{mm}$ and the total number of glomeruli was recorderd (670 glomeruli). Superficial, midcortical and juxtamedullary types of glomeruli are found (Figs. 10-11). The juxtamedullary glomeruli were approximately 1.5 and 1.8 times greater in average diameter than midcortical and superficial glomeruli respectively. The great number of glomeruli observed in the superficial region was about $267(39.8 \%)$ while in the midcortical was $282(42 \%)$ and $121(18 \%)$ in the juxtameduulary glomeruli (Table 4). The average diameter of glomeruli in the superficial region was $35.7 \pm 7.0 \mu$ while in midcortex it was $42.8 \pm 9.9 \mu$ and juxtamedullary glomeruli was $66.5 \pm 4.2 \mu$ (Table $5)$. 
The average glomerular volume of the superficial, midcortical and juxtamedullary glomeruli were about $1.72 \times 10^{9} \mu^{3}, \quad 7.6$ $\times 10^{9} \mu^{3}$ and $40.8 \times 10^{9} \mu^{3}$ respectively. The glomerular volume of the juxtameduulary glomeruli was approximately 23.7 and 5.3 times greater in average diameter than in superficial and midcortical glomeruli (Table $5)$. The relative glomerular blood volume (RGBV) of the juxtamedullary glomeruli was measured $2.6 \times 10^{12}$ and $2.16 \times 10^{12}$ in midcortical glomeruli, while that of superficial glomeruli it was about $4.6 \times 10^{11}$ (Table 6).

The proximal convoluted tubules were seen between the superficial glomeruli and renal capsule. The average diameter of proximal convoluted tubules was about 20.7 $\pm 2.8 \mu$. They appeared to be mainly the principle structure seen between the superficial glomeruli and the renal capsule (Fig. 10). The lumen of proximal convoluted tubule is the widest of any portion of the nephron. The internal lining is formed of cuboidal epithelial cells and sometimes it appeared as pyramidal shaped and resting on the basement membrane. The boundaries of these cells were almost indistinct and their ground cytoplasm was markedly eosinophilic and coarsly granular. They have centrally located nuclei which are large, spherical and rounded by darkly stained nuclear membranes and each one posse a peripherally located nucleolus. One of the characteristic features of the proximal convoluted tubule is the presence of a striated brush border of the free surface of its lining cells, which were lacking in any other part of the nephron. This border was distinctly eosinophilic and PAS positive such as the basement membrane of the tubules (Fig. 11). The lumen of the tubules was quite narrow in some sections and rather wide in other depending on the direction of sectioning.

The loop of Henle may be short, or long depending on the position of its renal corpuscle. It is differentiated into thin descending limb which extendes to the inner medulla and thick ascending limb which extended only in the outer medulla. The thin descending limb had a distinct rounded lumen. It could be clearly distinguished from the other parts of the nephron on the bases of its low lining epithelial cells (Fig. 12). The ground cytoplasm was homogenous eosinophilic in these cells and their nuclei are limited with distinct basophilic nuclear membrane and each nucleus has a single nucleolus.

At the vascular bundle, there are venous and arterial vasa recta beside to thin limb, the latter can be distinguished from the arterial vasa recta by the strongly stained PAS of the basal lamina of the arterial vasa recta as compared with the poor staining of the thin limb with PAS (Fig. 13). The ascending limb of loop of Henle appears larger in size than that of the descending limb and is enclosing a wider lumen. The epithelial cells lining of the ascending limb are generally of the low type but not as flattened as those of the descending one with distinct boundaries (Fig. 14). They have a homogenous eosinophilic cytoplasm. Their nuclei are spherical, located peripherally and deeply basophilic with distinct nucleoli. The nuclei being darker than those of descending limb with Mallory trichrome stain (Fig. 15). The diameter of descending limb was measured about $15.5 \pm 4.09 \mu$, while ascending limb was $21.5 \pm 1.0 \mu$.

The distal convoluted tubules were the second tubules of the cortex. The epithelial lining was of cuboidal type enclosing a rather extensive lumen. The ground cytoplasm of the distal tubule was clearly less eosinophilic than that of the proximal tubules. They have darkly basophilic rounded nuclei placed in the centers of the cells or a little near to the lumen (Fig. 15). The part of the distal convoluted tubule in contact with the glomerular root (the site of entrance of the efferent arterioles) has a rather modified appearance than the rest of these tubules. This region is identified as the macula densa that had elongated lining cells closely packed with faintly stained cytoplasm. The diameter of distal convoluted tubules was about $21.1 \pm 5.9 \mu$

The collecting tubule consists of epithelium that was quite different from other parts of the nephron. The epithelium of the collecting tubule in the outer medulla was of cuboidal one with rounded nuclei of moderate size and slightly basophilic cytoplasm. The collecting ducts were of considerable length, this was due to the length of renal papilla. In the upper part of 
the inner medulla, the epithelium in the last part of the renal papilla lined the collecting tubule becomes high cylindrical with large oval nuclei basally located with granulated apical cytoplasm (Fig. 16). The diameter of collecting tubule is measured $49.7 \pm 7.4 \mu$.

In Allactaga tetradactyla, the structure of the kidney is more or less similar to that of Psammomy obesus. The kidney was enveloped by renal capsule formed of connective tissue of eosinophilic nature in $\mathrm{Hx} \& \mathrm{E}$ stain (Fig. 17). The renal capsule is thinner than that in Psammomys obesus and the number of glomeruli in longitudinal section was about 315 which was fewer than that in Psammomys obesus. The number of glomeruli in the superficial region was recorded 133 glomeruli $(42.2 \%)$, while in midcortical was 117 $(37.1 \%)$ and $65(20.6 \%)$ in juxtamedullary (Table 4). The juxtamedullay glomeruli was recorded approximately 1.9 and 1.8 times greater in average diameter than the superficial and midcortical glomeruli respectively (Figs. 18-19).

The average glomerular volume of each zone in transverse sections of kidney was smaller than the glomerular volume of each zone in kidney of Psammomys obesus. The glomerular blood volume in superficial was about $1.23 \times 10^{9} \mu^{3}$ while in midcortical and juxtamedullary was recorded $3.68 \times 10^{9} \mu^{3}$ and $31.5 \times 10^{9} \mu^{3}$ respectively (Table 6). The glomerular volume of the juxtamedullary was approximately 25.6 and 8.5 times greater in average glomerular volume of superficial and midcortical glomeruli respectively. The relative glomerular blood volume of each zone of kidney was found to be lesser than that of Psammomys obesus. In superficial glomeruli, the relative glomerular blood volume was equal to $1.63 \times 10^{11}$ and in midcortical and juxtamedullary was about
$4.3 \times 10^{11}$ and $2.04 \times 10^{11}$ respectively (Table $6)$. The diameter of proximal convoluted tubules measures about $27.7 \pm 4.6 \mu$, which was greater than that in Psammomys obesus, with rounded lumen (Table 5). The boundaries of cells were indistinct with round nuclei which were located centrally and rest on basement membrane (Fig. 19).

The loop of Henle consists of ascending and descending limb of loop of Henle, the descending limb of loop of Henle extends in the outer and inner medulla. It has rounded lumen with cuboidal cells and round nuclei. The diameter of these cells was recorded $18.9 \pm$ $3.3 \mu$. It is thinner than that in Psammomys obesus and change from cuboidal to flattened cells (Fig. 20). The thick ascending ones have wider lumen than the descending one. The epithelium lining is high cuboidal cells greater than that found in the descending one (Fig. 21) and their diameter measures $20.3 \pm 0.8 \mu$.

The distal convoluted tubules were lined by low columnar cells with round and large nuclei. These cells rest on basement membrane. The diameter of this tubule was about $25.4 \pm 4.6 \mu$. The ground cytoplasm was stained red with $\mathrm{Hx} \& \mathrm{E}$ stain. The collecting tubule as in Psammomys obesus consists of different types of epithelial cells, the first which were in the outer medulla is cubical with round nuclei (Fig. 21). In the tip of papillae, the epithelium is high cylindrical in shape with large oval nuclei located centrally (Fig. 22). The diameter of collecting tubule is about $58.2 \pm 15.8 \mu$.

The vascular bundles were found beside the descending limbs of loop of Henle as in Psammomys obesus. They were composed of venous and arterial vasa recta and can be distinguished from the descending limb of loop of Henle by being strongly PAS positive (Fig. 23).

Table (1): Gross morphological measurements of rodent kidney

\begin{tabular}{|c|c|c|c|c|c|c|c|}
\hline \multirow{2}{*}{ Species } & No. of & Mean body & \multirow{2}{*}{$\begin{array}{c}\text { Mean } \\
\text { kidney } \\
\text { animals }\end{array}$} & \multirow{2}{*}{$\begin{array}{c}\text { Kidney } \\
\text { weight } \\
\text { /body } \\
\text { weight }(\mathrm{g})\end{array}$} & \multicolumn{3}{|c|}{ Thickness( mm/g $)$} \\
\cline { 6 - 9 } & & & weightx10 & Cortex & $\begin{array}{c}\text { Outer } \\
\text { medulla }\end{array}$ & $\begin{array}{c}\text { Inner } \\
\text { medulla }\end{array}$ \\
\hline Psammomys obesus & 10 & $133.6 \pm 29.1$ & $0.93 \pm 0.20$ & $0.83 \times 10^{-2}$ & 3.3 & 1.5 & 6.8 \\
\hline Allactaga tetradactyla & 10 & $48.3 \pm 9.01$ & $0.29 \pm 0.06$ & $0.6 \times 10^{-2}$ & 1.8 & 1.9 & 3.4 \\
\hline
\end{tabular}


Table (2): Measurements of dimensions of the kidneys of two rodent species.

\begin{tabular}{|c|c|c|c|c|c|}
\hline \multirow[b]{2}{*}{ Species } & \multicolumn{3}{|c|}{ Thickness (mm) } & \multirow{2}{*}{$\begin{array}{l}\text { Medulla } \\
\text { cortex } \\
\text { ratio }\end{array}$} & \multirow{2}{*}{$\begin{array}{l}\text { Inner medulla } \\
\text { length in } \% \text { of } \\
\text { medulla }\end{array}$} \\
\hline & Renal cortex & $\begin{array}{c}\text { Outer } \\
\text { medulla }\end{array}$ & Inner medulla & & \\
\hline Psammomys obesus & 1.20 & 1.12 & 6.16 & 5.59 & 79.6 \\
\hline Allactaga tetradacty & 0.82 & 0.94 & 4.9 & 2.9 & 64.1 \\
\hline
\end{tabular}

Table (3): Statestical data of measurements of hepatic cells of Psammomys obesus and Allactaga tetradactyla

\begin{tabular}{|c|c|c|c|c|c|c|c|c|}
\hline & & $\begin{array}{c}\text { No. of } \\
\text { cells }\end{array}$ & $\begin{array}{c}\text { Mitotic } \\
\text { cell }\end{array}$ & $\begin{array}{c}\text { Mitotic } \\
\text { index }\end{array}$ & $\begin{array}{c}\text { Vol. of } \\
\text { cells }\end{array}$ & $\begin{array}{c}\text { Vol. of } \\
\text { nucleus }\end{array}$ & $\begin{array}{c}\text { Vol. of } \\
\text { Cytoplasm }\end{array}$ & $\begin{array}{c}\text { Nucleocyto } \\
\text { plasmic } \\
\text { index }\end{array}$ \\
\hline \multirow{2}{*}{$\begin{array}{c}\text { Psammomys } \\
\text { obesus }\end{array}$} & Average & 6.556 & 4.489 & 68.277 & 41.703 & 13.934 & 27.768 & 56.368 \\
\cline { 2 - 9 } & SD & 1.391 & 1.272 & 10.227 & 11.105 & 3.232 & 10.845 & 20.687 \\
\hline \multirow{2}{*}{$\begin{array}{c}\text { Allactaga } \\
\text { tetradactyla }\end{array}$} & Average & 7.273 & 3.409 & 45.844 & 31.740 & 12.925 & 17.759 & 75.335 \\
\cline { 2 - 9 } & SD & 1.897 & 1.896 & 19.214 & 4.902 & 1.400 & 5.231 & 31.250 \\
\hline
\end{tabular}

Table (4): The glomerular number and percentages for three cortical zones of the kidneys of Psammomys obesus and Allactaga tetradactyla

\begin{tabular}{|l|c|c|c|c|c|c|c|}
\hline \multirow{2}{*}{ Species } & \multirow{2}{*}{$\begin{array}{c}\text { Number of } \\
\text { glomeruli }\end{array}$} & \multicolumn{2}{c|}{ Superficial } & \multicolumn{2}{c|}{ Midcortical } & \multicolumn{2}{c|}{ Juxtamedullary } \\
\cline { 3 - 8 } & Number & $\%$ & Number & $\%$ & Number & $\%$ \\
\hline Psammomys obesus & 670 & 267 & 39.8 & 282 & 42 & 121 & 18 \\
\hline Allactaga etradactyla & 315 & 133 & 42.2 & 117 & 37.1 & 65 & 20.6 \\
\hline
\end{tabular}

Table (5): Numbers and diameter of glomeruli for three cortical zones of Psammomys obesus and Allactaga tetradactyla

\begin{tabular}{|c|c|c|c|c|c|c|c|}
\hline \multirow{2}{*}{ Species } & \multirow{2}{*}{$\begin{array}{c}\text { Total number } \\
\text { of glomeruli }\end{array}$} & \multicolumn{3}{|c|}{ No. of glomeruli } & \multicolumn{3}{c|}{ Diameter of glomeruli } \\
\cline { 4 - 8 } & & Cortex & Midcortical & Juxtamedullary & Cortex & Midcortical & Juxtamedullary \\
\hline $\begin{array}{c}\text { Psammomy } \\
\text { s obesus }\end{array}$ & 670 & 267 & 282 & 121 & $48.8 \pm 5.3$ & $42.8 \pm 9.9$ & $67.1 \pm 8.01$ \\
\hline $\begin{array}{c}\text { Allactaga } \\
\text { tetradactyla }\end{array}$ & 315 & 133 & 117 & 65 & $37.2 \pm 8.02$ & $41.1 \pm 7.08$ & $48.2 \pm 9.3$ \\
\hline
\end{tabular}


Anatomical, Histological And Histochemical Studies On.

Table (6): The glomerular blood volume and relative glomerular blood volume for three cortical zones of the kidney of two rodent species

\begin{tabular}{|c|c|c|c|c|c|c|}
\hline \multirow{2}{*}{ Species } & \multicolumn{2}{|c|}{ Superficial } & \multicolumn{2}{c|}{ Midcortical } & \multicolumn{2}{c|}{ Juxtamedullary } \\
\cline { 2 - 7 } & $\begin{array}{c}\text { Glomerular } \\
\text { blood } \\
\text { volume }\end{array}$ & $\begin{array}{c}\text { Relative } \\
\text { glomerular } \\
\text { blood } \\
\text { volume }\end{array}$ & $\begin{array}{c}\text { Glomerular } \\
\text { blood } \\
\text { volume }\end{array}$ & $\begin{array}{c}\text { Relative } \\
\text { glomerular } \\
\text { blood } \\
\text { volume }\end{array}$ & $\begin{array}{c}\text { Glomerular } \\
\text { blood } \\
\text { volume }\end{array}$ & $\begin{array}{c}\text { Relative } \\
\text { glomerular } \\
\text { blood } \\
\text { volume }\end{array}$ \\
\hline $\begin{array}{c}\text { Psammomys } \\
\text { obesus }\end{array}$ & $1.72 \times 10^{9} \mu^{3}$ & $4.6 \times 10^{11}$ & $7.6 \times 10^{9} \mu^{3}$ & $2.16 \times 10^{12}$ & $40.8 \times 10^{9} \mu^{3}$ & $2.6 \times 10^{12}$ \\
\hline $\begin{array}{c}\text { Allactaga } \\
\text { tetradactyla }\end{array}$ & $1.23 \times 10^{9} \mu^{3}$ & $1.63 \times 10^{11}$ & $3.68 \times 10^{9} \mu^{3}$ & $4.3 \times 10^{11}$ & $31.5 \times 10^{9} \mu^{3}$ & $2.04 \times 10^{12}$ \\
\hline
\end{tabular}

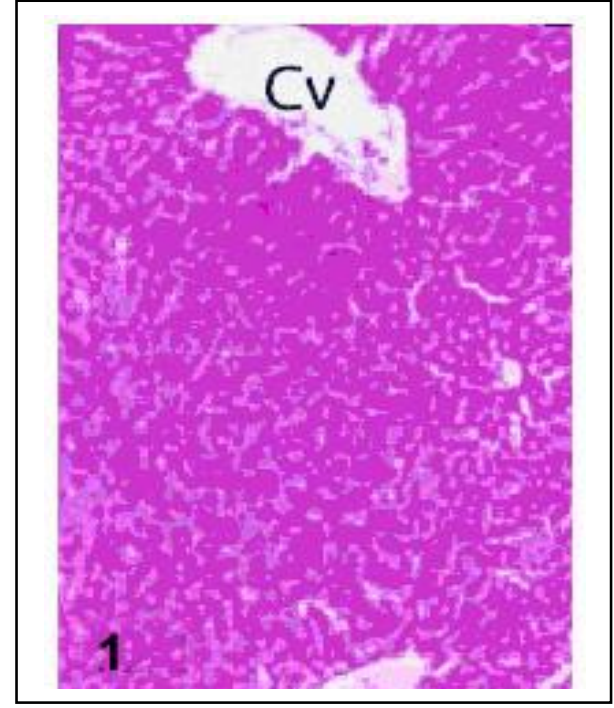

Fig. (1): Photomicrograph of $S$. of the liver of Psammomys besus. (Hx \& E stain X 100)

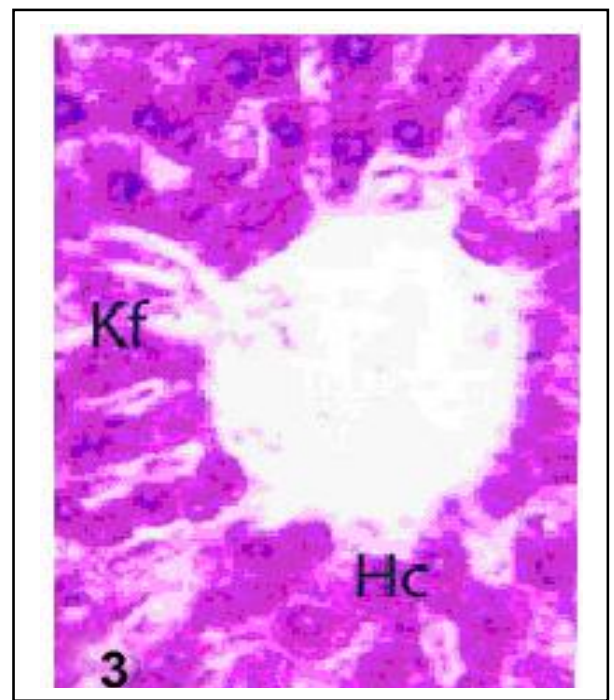

Fig. (3): Photomicrograph of S. of the liver of Psammomys obesus. (Hx \& E stain X 400)

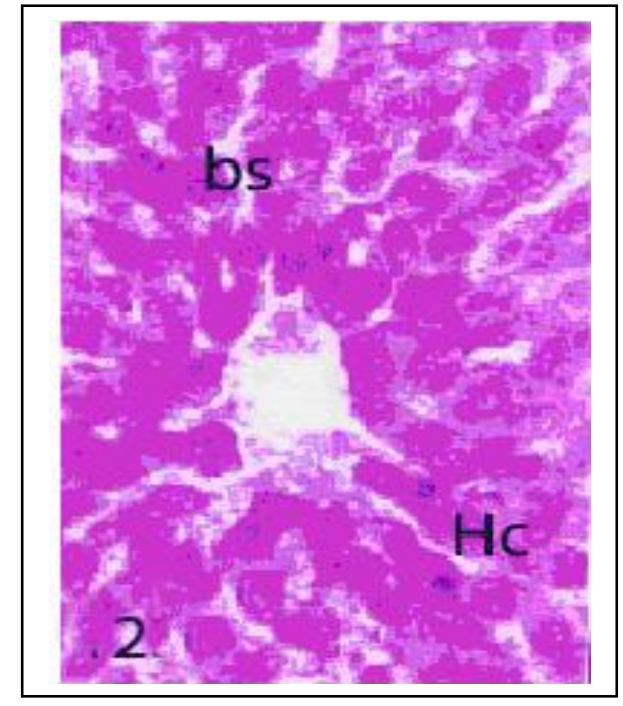

Fig. (2): Photomicrograph of S. of the liver of Psammomys obesus (Hx \& E stain X 400)

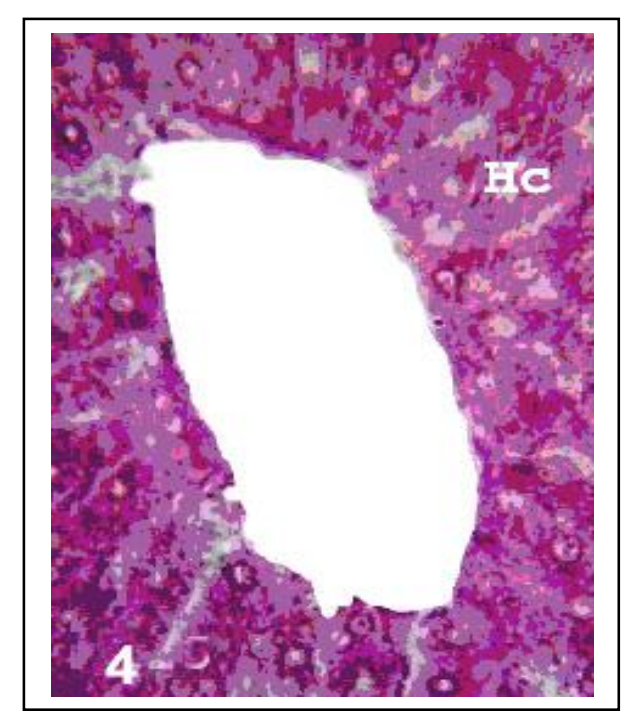

Fig.(4): Photomicrograph of S. of the liver of Allactaga tetradactyla (AB- PAS stain X 400) 
Boshra A. El- Salkh et al

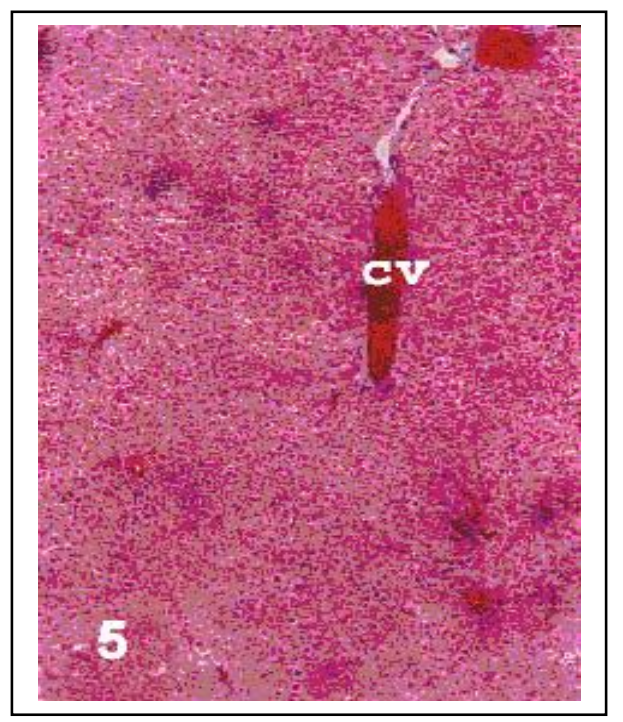

Fig. (5): Photomicrograph of S. of the liver of Allactaga tetradactyla

(Mallory trichrome stain X 100)

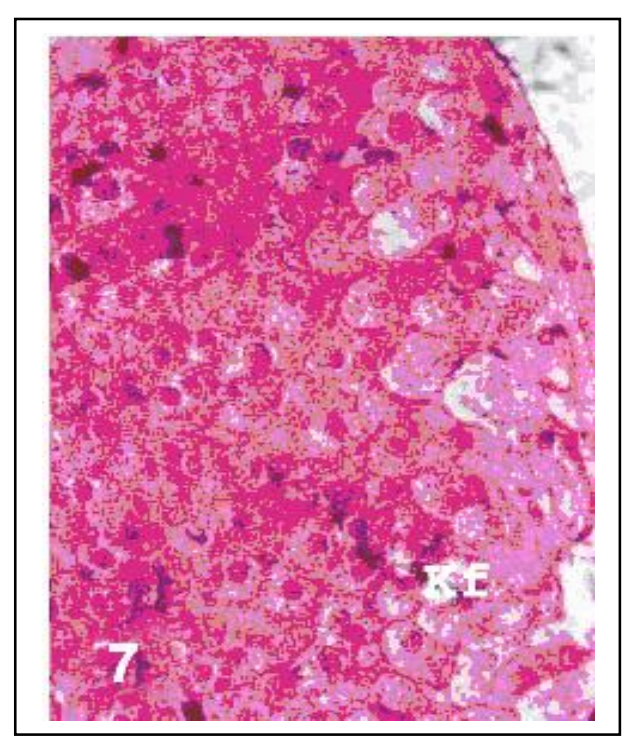

Fig. (7): Photomicrograph of S. of the liver of Allactaga tetradactyla. (Hx \&E stain X 400)

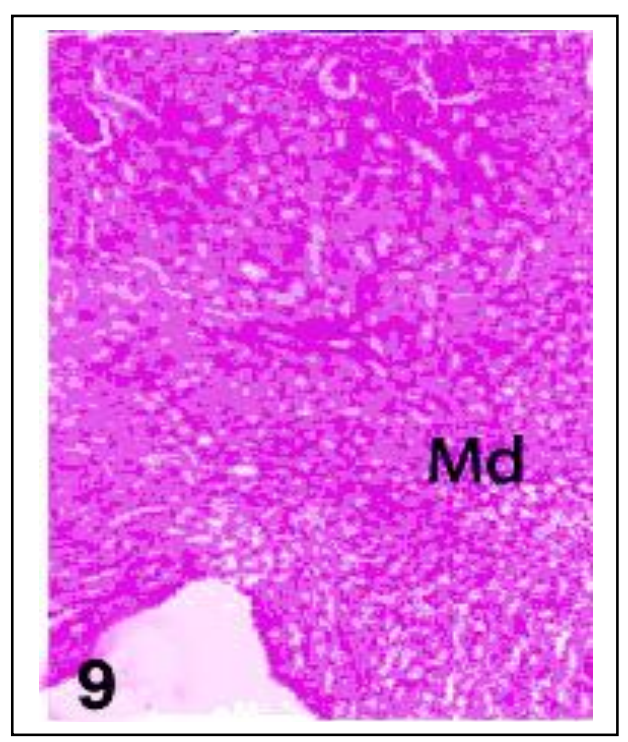

Fig. (9): Photomicrograph of a L.S of the kidney of Psammomys obesus (Hx \& E stain X100)

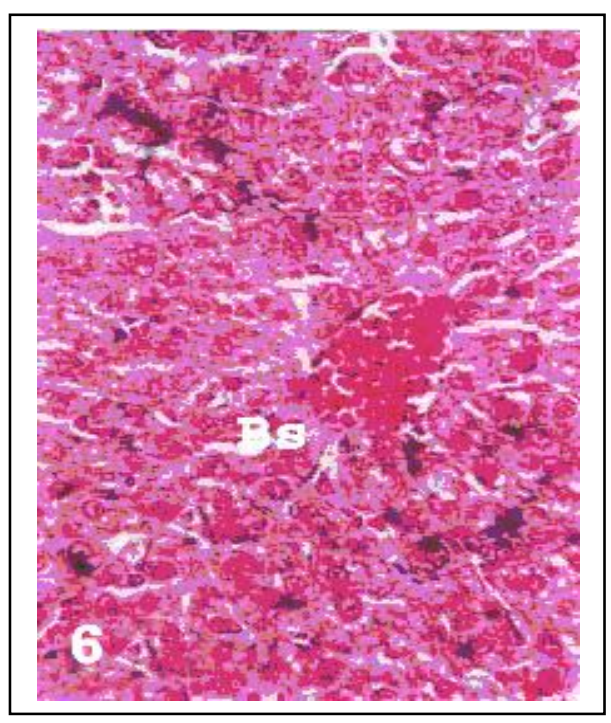

Fig. (6): Photomicrograph of S. of the liver of Allactaga tetradactyla

(Mallory trichrome stain X 400)

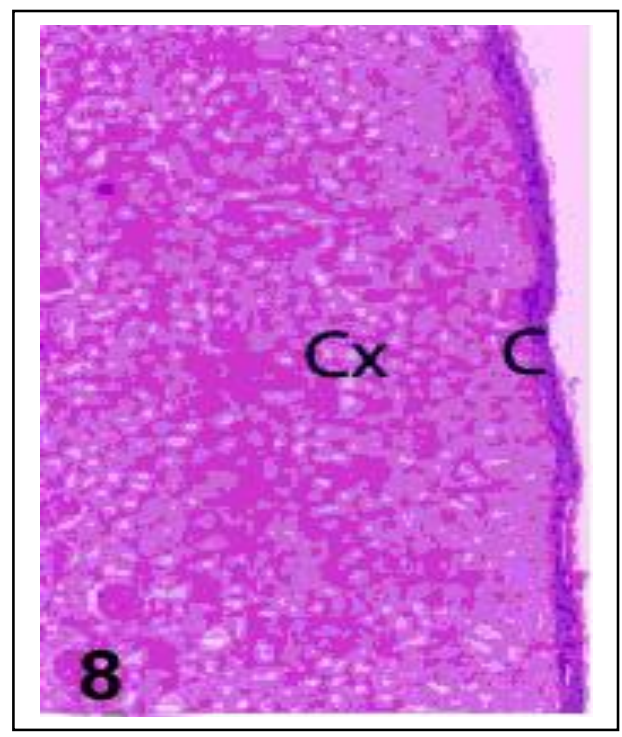

Fig. (8): Photomicrograph of a L.S of the kidney of Psammomys obesus $\quad$ (Hx \& E stain X100)

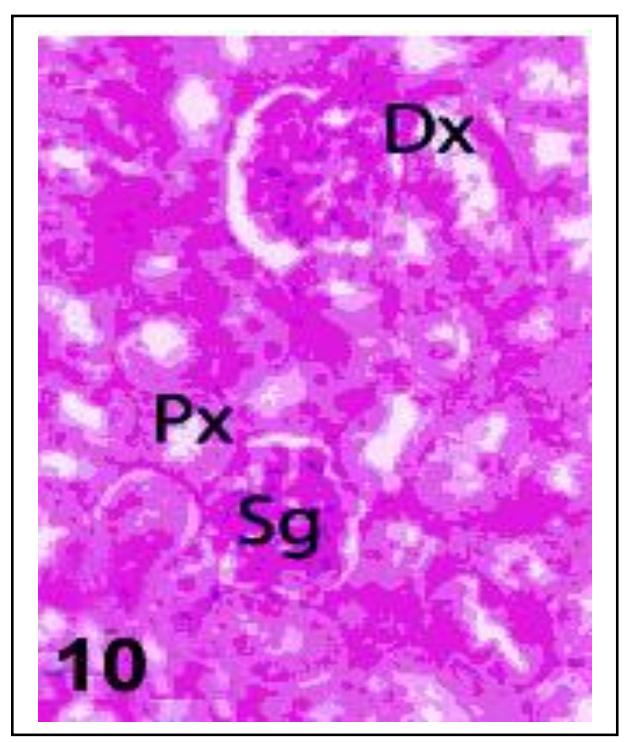

Fig. (10): Photomicrograph of a L.S of the kidney of Psammomys obesus 


\section{Anatomical, Histological And Histochemical Studies On.}

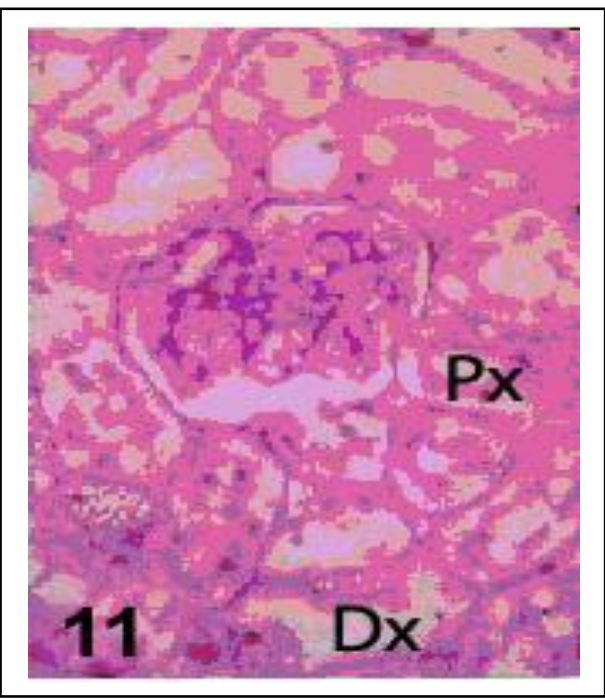

Fig. (11): Photomicrograph of a L.S of the kidney of Psammomys obesus （AB- PAS stain X400)

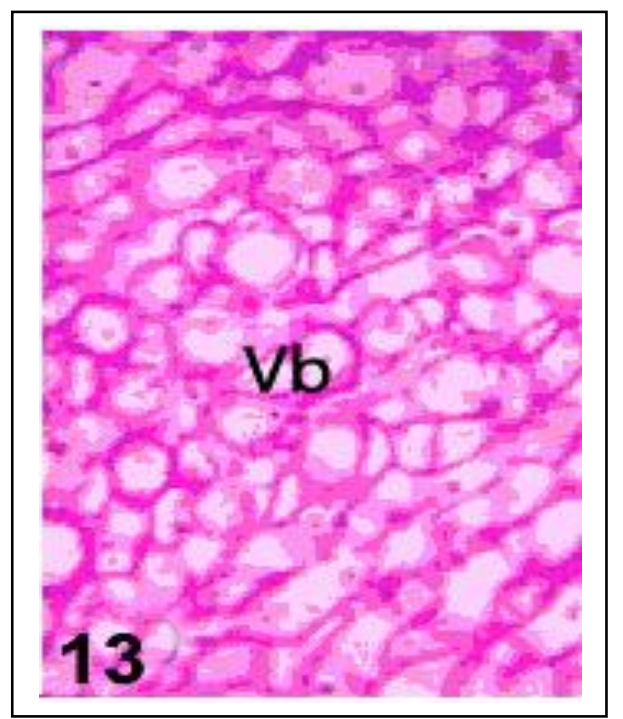

Fig. (13): Photomicrograph of a L.S of the kidney of Psammomys obesus. (AB- PAS stain X400)

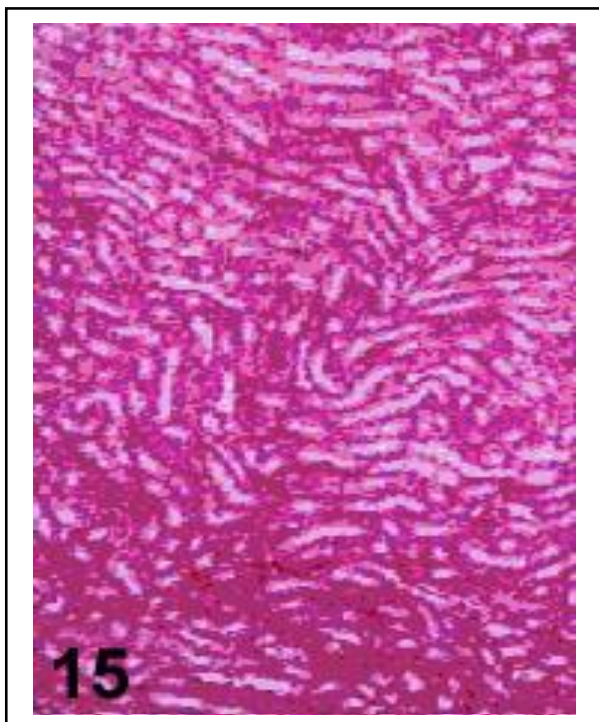

Fig. (15): Photomicrograph of a L.S of the kidney of Psammomys obesus

(Mallory trichrome stain X100)

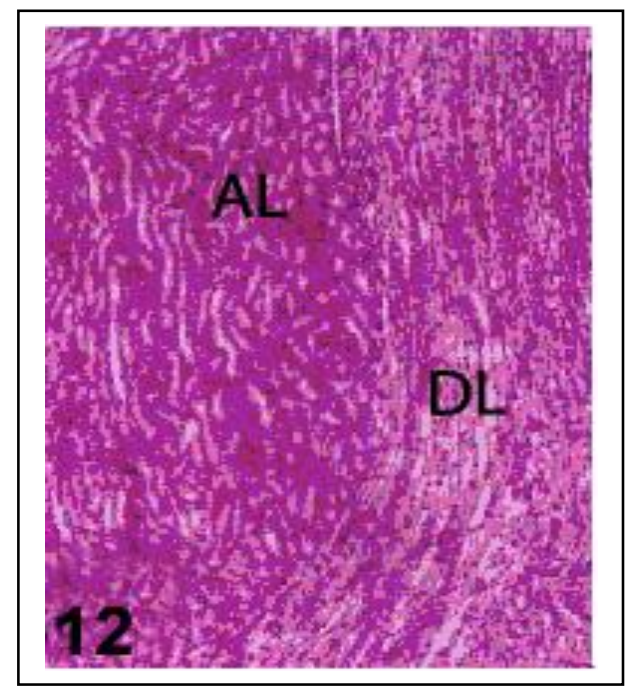

Fig. (12): Photomicrograph of a L.S of the kidney of Psammomys obesus $\quad$ (Hx \& E stain X100)

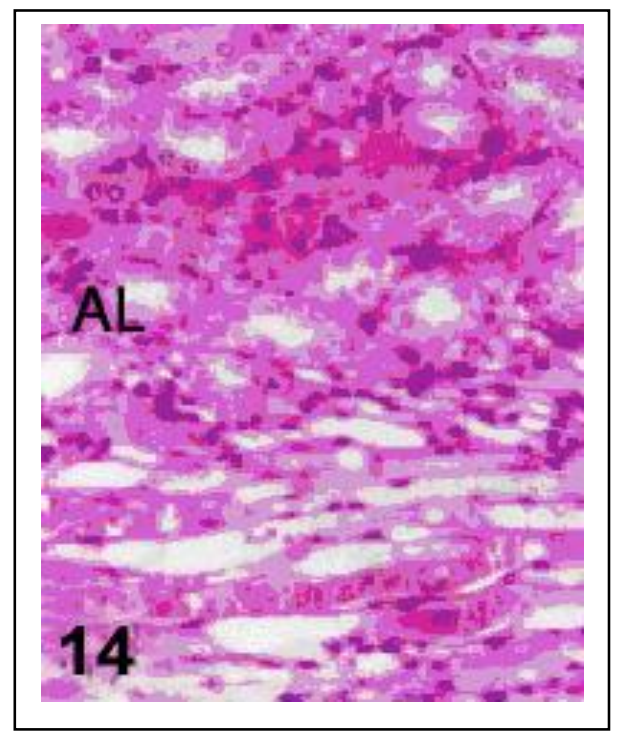

Fig. (14): Photomicrograph of a L.S of the kidney of Psammomys obesus (Hx \& E stain X400)

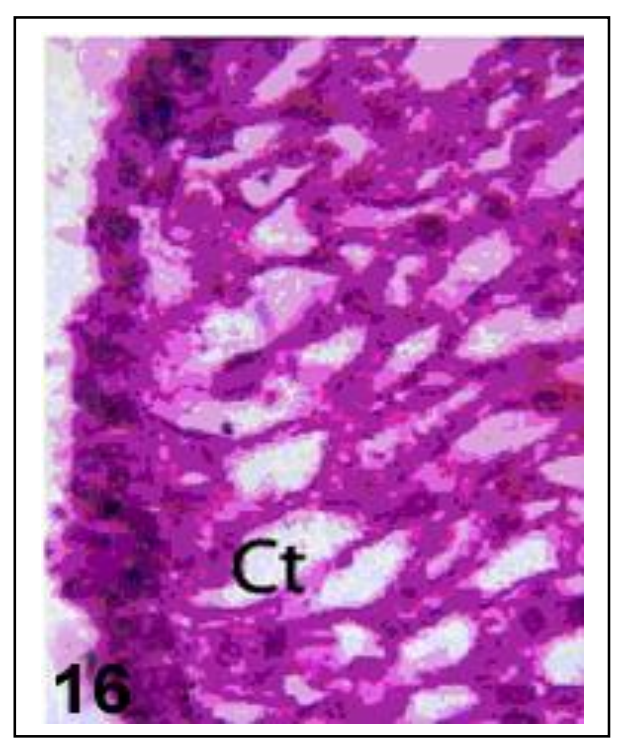

Fig. (16): Photomicrograph of a L.S of the kidney of Psammomys obesus. (Hx \& E stain X 400) 
Boshra A. El- Salkh et al

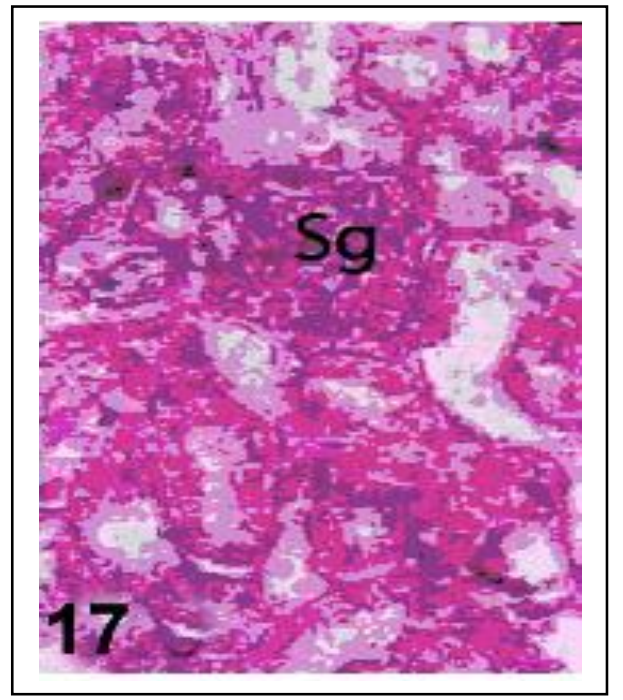

Fig. (17): Photomicrograph of a L.S of the kidney of Allactaga tetradactyla

(Mallory trichrome stain X 400)

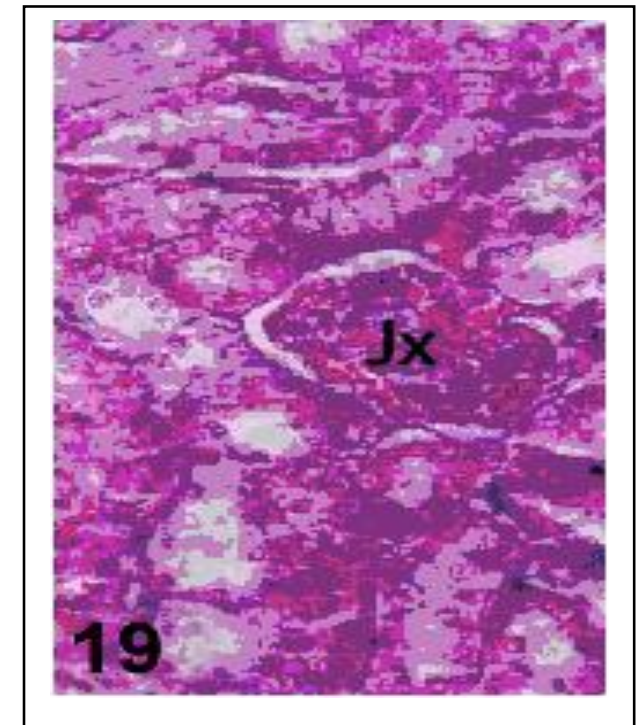

Fig. (19): Photomicrograph of a L.S of the kidney of Allactaga tetradactyla.

(Mallory trichrome stain X 400)

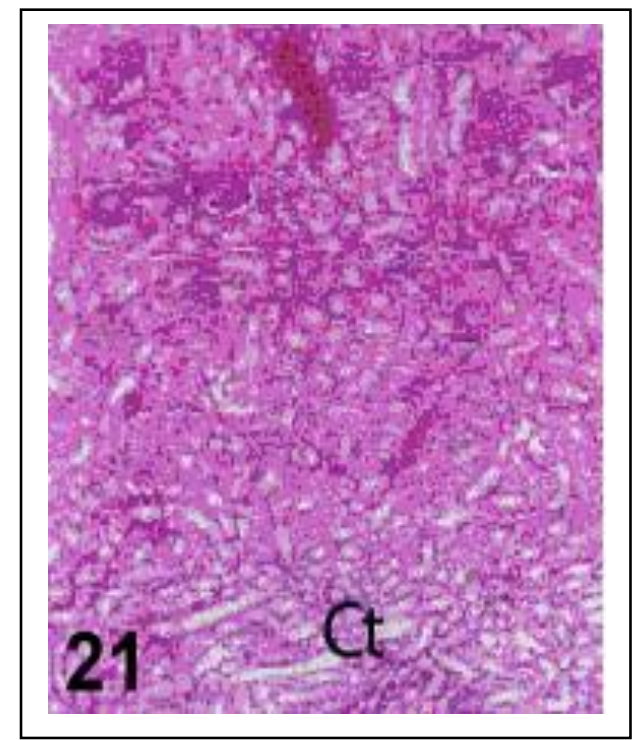

Fig. (21): Photomicrograph of a L.S of the kidney of Allactaga tetradactyla

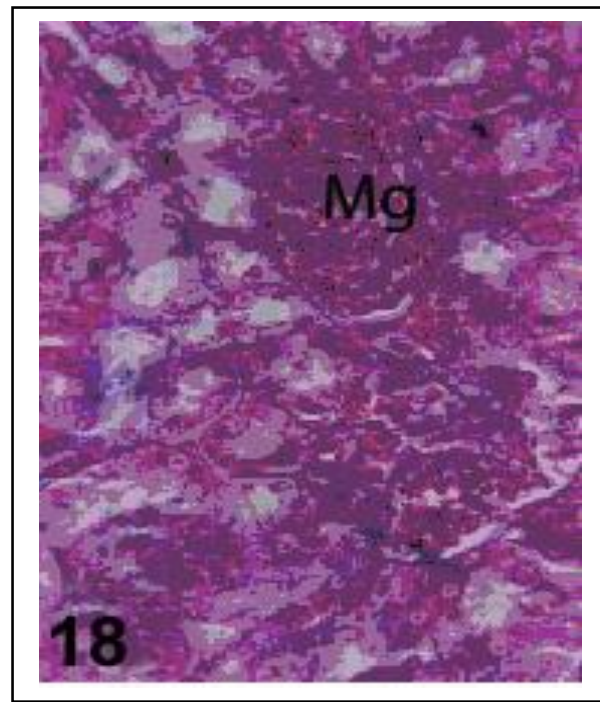

Fig. (18): Photomicrograph of a L.S of the kidney of Allactaga tetradactyla

(Mallory trichrome stain X 400)

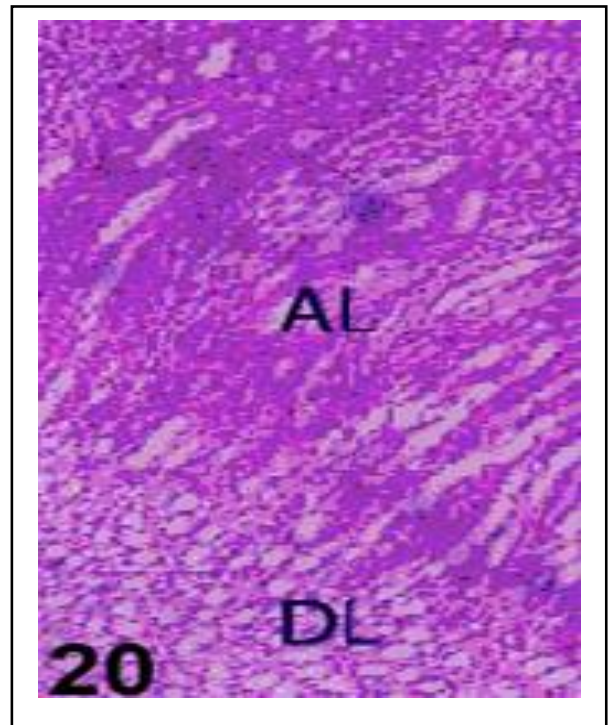

Fig. (20): Photomicrograph of a L.S of the kidney of Allactaga tetradactyla (Hx \& E stain X 100)

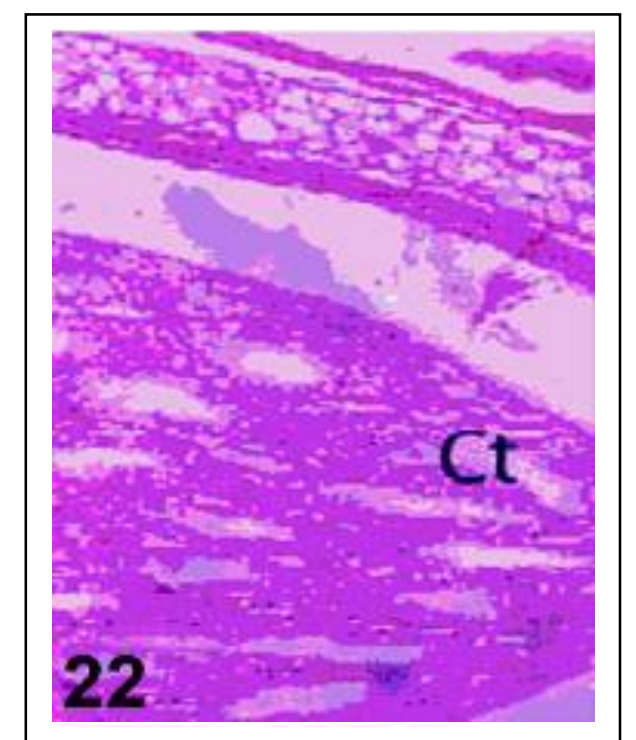

Fig. (22): Photomicrograph of a L.S of the kidney of Allactaga tetradactyla.

(Hx \& E stain X 400) 


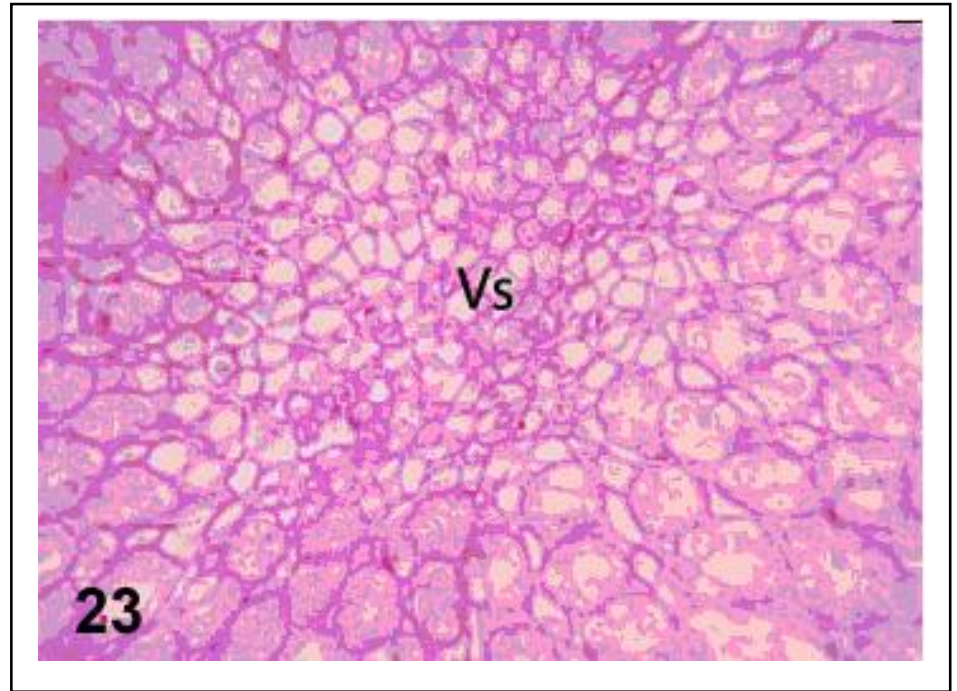

Fig. (23): Photomicrograph of a L.S of the kidney of Allactaga tetradactyla

\section{List of abbreviations:}

$\mathrm{AL}=$ ascending limb of loop of Henle;

Bs = blood sinusoid;

$\mathrm{Ct}=$ collecting tubules;

$\mathrm{Cv}=$ central vein;

$\mathrm{Cx}=$ cortex;

$\mathrm{DL}=$ descending limp of loop of Henle;

$\mathrm{Dx}=$ distal convoluted tubules.

$\mathrm{gc}=$ goblet cell.

(AB - PAS stain X 400)

$\mathrm{Hc}=$ hepatic cell;

$\mathrm{Jx}=$ juxtamedullary glomeruli;

$\mathrm{Kf}=$ kupffer cell;

$\mathrm{Mc}=$ mucous cell.

$\mathrm{Mg}=$ midcortical glomeruli;

$\mathrm{Px}=$ proximal convoluted tubules;

$\mathrm{Sg}=$ superficial glomeruli;

$\mathrm{Vb}=$ vascular bundle;

\section{Discussion}

The present study comprises two types of rodent species, one of them was called fat sand rat Psammomys obesus, it lives in the coastal and presaharan region, frequently diurnal and feeds on halophytic plants (Zaime and Gauter, 1989). The second rodent was called four-toed jerboa Allactaga tetradactyla. It was found in salt marshes and clay desert areas of coastal plains. It was a nocturnal rodent and feeds on seeds and succulent plants especially with milky juices. It did not drink water at all, but lives on metabolic water produced by the chemical breakdown of food (MacDonald, 1984).

The liver of the two investigated rodents is the largest gland in the body, located interiorly in the abdominal cavity just behind the diaphragm. It consists of five lobes. This description was similar to those described for Mustela nivalis as mammalian species (El-Naggar, 1989). In the two investigated species, the liver was a compund tubular gland covered by thin layer of peritoneal epithelium formed of flattened cells resting on a thin basement membrane (Leeson et al., 1988). Each lobe was subdivided by connective tissue into polyhedral lobules and interlobular connective tissue restricted to the portal canal at the angles of the lobules. This confirms the findings of Basuony (1993).

In Psammomys obesus, the hepatic lobule was prismatic in shape with a central vein forming its central axis. It was built up of columns of hepatic cells, hepatocytes, which radially arranged from the central vein to the periphery of the lobule. The hepatocytes were polygonal in shape; each cell possesses a distinct limiting membrane. Nuclei of hepatocytes were spherical or ovoid with a regular surface. Occasionally binucleated cells were present. More or less similar observations were recorded by El- 
Naggar (1989) on the liver of Mustela nivalis. In Allactaga tetradactyla, the lobulation of liver was less distinct than that in Psammomys obsus. The mitotic index in Allactaga tetradactyla was graeter than that in Psammomys obesus, this observation may be due to the increase the activity of Allactaga tetradactyla. The liver gave PAS positive reaction which indicates the secretion of both acid and neutral mucosubstances. This result was in agreement with Basuony (1993).

The urinary system of rodents was composed of two kidneys, ureter, urinary bladder and urethera. This structure was similar in all mammals (Young, 1975). The paired kidneys of the two investigated rodents were bean-shaped and dark red bodies located in the dorsal wall of the abdominal cavity. The general histological structure of the kidney displays a capsule, outer cortex and inner medulla.

The kidney was enclosed in a thin fibroconnective tissue capsule, this was in agreement with Ali (1978). The cortex was composed of many rows of glomeruli. This was maybe due to the higher thickness of the cortex, a similar observation had been described in Meriones libycus kidneys by Basuony (1993). The thickness of cortex in Psammomys obesus is $1.32 \mathrm{~mm}$, however, in Allactaga tetradactyla measured about $0.82 \mathrm{~mm}$. In the kidney of Psammomys obesus, there was a great variation in size between glomeruli. The juxtamedullary glomeruli were approximately 1.5 and 1.8 times greater in average diameter than midcortical and superficial glomeruli respectively. This lead to preferential filtration in these nephrons and because they have long loops, and this may result in maximal concentrating capacity. Similar observations were recorded by Hanssen (1961) and Basuony (1997). On the other hand Allactaga tetradactyla juxtamedullary glomeruli were approximately 1.9 and 1.8 times greater in average diameter than the superficial and midcortical glomeruli respectively. Munkacsi and Palkovits (1965) mentioned that the juxtamedullary glomeruli were $101 \%$ bigger than the cortical ones in $J$. jaculus (desert animal), $169 \%$ in Galago senegalensis (semidesert animal) and $28 \%$ in Rattus norvigicus (water requiring animal).
The glomerular constituents include podocytes, capillary, endothelial cells and connective tissue which were PAS positive. A more or less similar observations had been described in the kidney of rabbit by Foster and Riad (1963) and of desert gerbil Meriones crassus by Safer et al. (1990) and Abd-Elgawwad (1999). The variation between superficial, midcortical and juxtamedullary glomeruli was the first adaptation which had been observed in the kidney of desert rodent (Munkacsi and Palkovits, 1965 and Basuony, 1993). This variation in size leads one to suspect that the glomerular filteration surface would be much greater in the large juxtamedullary population of glomeruli, this could lead to preferential filtration in these nephrons and because they have long loops many results indicated maximal concentrating capacity. According to the previous observations, the kidney in Psammomys obesus had greater filteration capacity than that found in Allactaga tetradactyla. This finding agrees with Hanssen (1961) who stated that, the glomerular filtration rate of the juxtamedullary nephron is approximately eight times that of nephron from the outer cortex and the glomerular shape in the two species was spherical (Munkacsi and Palkovits, 1965 and Basuony, 1993). The variation in number of glomeruli in the kidney does not provide direct influence on the ability to produce concentrated urine. This finding was in agreement with Abdalla and Abdalla (1979).

The second adaptation of desert rodent was an increased elongation of the inner medullary portion of the kidney of Psammomys obesus when compared to that found in Allactaga tetradactyla, this result agree with the gross adaptation of desert species especially rodents (Basuony 1993). On the other hand, they mentioned that the relative thickness of the medulla was related to their habit of the animal. The lengthening of the papillae was associated with the lengthening of the collecting ducts and therfore results in an increased area for water recovery through passive back diffution under the influence of antidiuretic hormone (Schimdt-Nielsen and O'Dell, 1961; Berliner and Bennet, 1967; March and Segel, 1971). Similar results were obtained in the present investigation. The 
lengths of papillae were found to be greater in Psammomys obesus than that recorded in Allactaga tetradactyla.

The average diameter of both proximal convoluted tubules and distal convoluted tubules in Psammomys obesus was less than that in Allactaga tetradactyla. The internal lining was formed of cuboidal epithelial cells with indistinct boundaries and their ground cytoplasm was eosinophilic and coarsely granular while their central nuclei were basophilic. Neutral mucosubstance was also investigated in the striated brush border which gave PAS positive reaction. Vasa recta found in both species and this was related directly to urine concentrating ability (Munkacsi and Palkovits, 1977). The thin loop can be distinguished from the arterial vasa recta by their bundles. PAS reaction allows an easier differentiats due to the strong affinity of the basal lamina of arterial vasa recta as compared with poor stainning in the loops. The vasa recta were considered to participate in the countercurrent system thus preventing the blood flow to the medulla from washing away the concentration gradient as indicated by Berliner and Bennett (1967), Munkacsi and Palkovits (1977), Mona et al. (2007) and Hajime et al. (2008). The medulla cortex ratio was recorded higher in Allactaga tetradactyla (2.9\%) than in Psammomys obesus (2.5\%). In both species, the epithelium at the middle of the outer zone of papilla changes from cuboidal to flattened cells. At a certain zone in the papilla approximtely at the limit between the middle and distal third of the papilla, the epithelium of flattened cells becomes again cuboidal. This result was also observed in kangaroo rat by Vimtrup and Schmidt-Nielsen (1952) and in cricetid rodents by Khalil and Tawfic (1963) and Basuony (1993). These finding support the current physiological view that hypertonic urine was formed by active water reabsorption in the distal and collecting ducts. The high efficiency of the kidney and its role in the conservation of water depends on the previous observations (Khalil and Tawfic, 1963).

\section{References}

1. Abdalla M A and Abdalla O (1979): Morphometric observations on the kidney of the Camel, Camelus dromedarius. J. Anat., 129: 45-50.

2. Abd-Elgawwad H A (1999): Comparative anatomical studies on some rodents and their correlation with ecosystem. M. Sc. Thesis, Al-Azhar University, Cairo for Girls.

3. Ali N H (1978): Comparative histological and histochemical studies on the kidney of vertebrates. M.Sc. Thesis, Zool. Dep. Fac. Sci. Ain Shams Univ. Cairo, Egypt.

4. Altaschuler E M; Nagla R B; Braun E J; Linstedt S L and Krutzsch P H (1979): Morphological study of the desert heteromyid kidney with emphasis on the genus perognathus. Anat. Rec., 194: 461 468

5. Basuony M I (1993): Habitat partitioning on anatomical basis among rodents of a desert ecosystem. Ph.D. Thesis, Al-Azhar University, Cairo.

6. Basuony M I (1997): Ecological variability and kidney structure of eight desert rodents. Egypt. J. Histol., 20 (2): 417-434

7. Basuony M I; Salem M Mand Younis M I (2009): Kidney variability in two foxes in Egypt. Al-Azhar Bull. Sci. (in press).

8. Berliner $R W$ and Bennett $C H$ (1967): Concentration of the urine in the mammalian kidney. Am. J. Med., 42: 777- 789.

9. Degan A A (1993): Energy requirements of the fat sand rat (Psammomys obesus) when consuming the salt bush, Atriplex halimus: a review. J. Basic Clin. Physiol. Pharmacol., 4 (1-2): 13-28

10. EL-Banhawy M A; Demian E S; Shalaby A A and Roshdy M A (1972): Text Book of Zoology. Dar Al-Maaref, 1119 Cornishe Enile, Cairo, Egypt.

11. EL-Naggar E R (1989): Studies on the Weasel Mustela nivalis subpalmate M.Sc.Thesis Dept. Zool. Fac. Sci. Tanta University, Egypt.

12. Foster C I and Riad Z M (1963): Some staining properties of the glomerular constituents in normal rabbits. J. Anat., 97: 403-407.

13. Hajime F; Hiroshi N; Koji W; Bernadene A and Ashley R. (2008): Acute, subchronic and genotoxicity conducted with Oligonol, an oligomerized polyphynol formulated from lychee and 
green tea extracts. J. Food and Chem. Toxi., (46) 3553-3562.

14. Hanssen D E (1961): The frequency of temporarily inactive glomeruli in mice under physiologic condition. Acta Pathol. Microbiol. Scan., 53: 253-259.

15. Happold D C D (1984): Small Mammals in Sahara Desert: 251-275. CloudsleyThompson, J. L. (ed.,) pergamon press, Oxford, London.

16. Hendrickson R (1983): More Cunning Than Man and Men. New York, Stein and Day publishers.

17. Hickman P C; Roberts $\mathbf{S} \mathbf{L}$ and Hickman M F (1984): Integrated Principles of Zoolgy. $7^{\text {th }}$ Edition Times Mirror, Mosby college publishering st. Lours Tornto Santa Clara. Canada.

18. Kaissling B; Rouffignac C D; Barrett J $M$ and Krz W (1975): The structural organisation of the kidney of the desert rodent, Psammomys obesus. Anat. Embry., 148: 121-143.

19. Khalil F and Tawfic J (1963): Some observations on the kidney of the desert $J$. Jaculus and G. gerbillus and their possible bearing in the water economy of these animals. J. Exp. Zool., 154: 259-271.

20. Leeson T S; Leeson $\mathbf{C} \mathbf{R}$ and Paparo AA (1988): Text Atlas of Histology. W. B. Sounders Co., USA.

21. MacDonald D (1984): Encyclopedia of Mammals Facts on File publications, New York

22. March D J and Segel L A (1971): Analysis of countercurrent diffusion exchange in blood vessels of the renal medulla. Am. J. Physiol., 221: 817-828

23. Marquie G; Duhault $J$ and Jactor $B$ (1984): Diabetes mellitus in Sand Rat (Psammomys obesus). Metabolic pattern during development of the diabetic syndrome. Diabetes, 33 (5): 438-443

24. Mc Manus JPA (1946): Histological demonstration of mucin after periodic acid. Nature (London), 158(4006): 202.

25. Mona A H Y; Sabah G E and Aly B O (2007): Diazinon toxicity affects histophysiological and biochemical parameters in rabbits. Exper. and Toxi. Patho., (59) 215-225.

26. Munkacsi I and Palkovits M (1965): Volumetric analysis of glomerular size in kidneys of mammals living in desert, semidesert or water- rich environment in the Suda. Circ. Res., 17: 303-311.

27. Munkacsi I and Palkovits M (1977): Measurments on the kidney and vasa recta of various mammals in relation to urine concentrating capacity. Acta Anat., 98: 456-458.

28. Novikoff A B and Essner E (1960): The liver cell: some new approaches to its study. Amer. J. Med., 29: 102-131.

29. Nowak R M (1991): Mammals of the World. $5^{\text {th }}$ edition. Jhons Hopkins University press and Baltimore

30. Osborn D J and Helmy I (980): The contemporary land mammals of Egypt (including Sinai), Fieldiana (Zool.) 5: 1-59

31. Palkovits $M$ and Zolani $B$ (1963): Quantitative histologic method zur statistischen untersuchung des volumes der inerenglomeruli deren anteil an der nierenrinde-3 Wiss. Mikroscopie, 65: 342-361.

32. Pearse A G E (1968): Histochemistry Theoretical and Applied. Vol. 1, Churchill Livingstone Publ. London.

33. Purohit K G and Ghosh P K (1963): Histological and histochemical studies of tissues of two desert rodents. Meriones hurrianae and Tetra Indica. Ann. Arid zone, 2: 26-34.

34. Safer A M; Al-Ajami $\mathbf{N}$ and Bou-Resli $\mathbf{M}$ N (1990): Presence of vesicular bodies and thick basal laminae in the nephron of the desert gerbil, Meriones crassus. Acta Anat., 137: 261-271.

35. Schmidt-Nielsen K and O'Dell R (1961): Structure and concentrating mechanism in the mammalian kidneys. Amer. J. Physiol., 200: 1119-1124.

36. Vimtrup $B$ and Schmidt-Nielsen $B$ (1952): The histology of the kidney of kangaroo rats. Anat. Rec., 114: 515-528.

37. Wilson $\mathbf{S}$ and Reeder A (2005): Mammal species of the world. Jhons Hopkins University press and Baltimore

38. Young Z J (1975): The Life of Mammals; Their anatomy and Physiology, second edition, claredom press Oxford.

39. Younis M M (2008): Environmental impacts of different habitats on kidney structure and function of some mammals. M.Sc. Thesis, Al-Azhar University, Cairo.

40. Zaime A and Guater J Y (1989): Comparison des regions alimentaires de trois especes sympatriques de gerbillidae en mileu Saharian, au Maroc. Rev. Ecol., 44: 153-163.

41. Zaki Z T (1993): Histological and functional relationship of the kidney of hedgehogs. Egypt. J. Histol., 16 (2): 451 - 466.

42. Zaki Z T; Basuony M I and Ibrahim I G (1994): Ecological significance of anatomical and histological structure of some mammalian kidney. Egypt. J. Histol., 17(1): 193-208. 


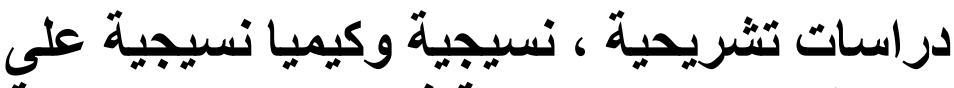 بعض أعضاء القوارض الصحر اوية فى بيئاتها الصحراوية الصية المصرية}

\section{بشرى عبد العزيز السلخ ، زكى توفيق زكي **، محمد ابراهيم بسيونى ** و}

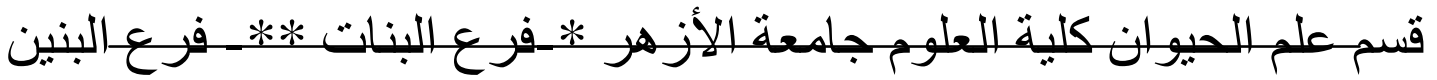

يتضمن هذا البحث در اسات على نوعين من القوارض الصحر اوية يعرفان باسم فأر

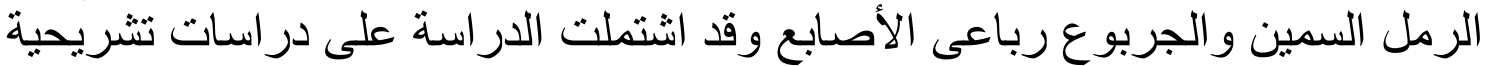

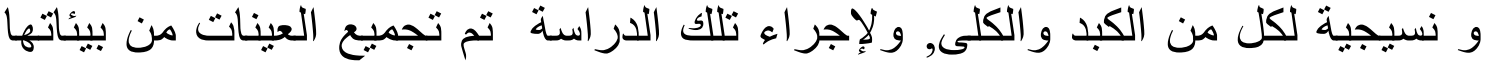

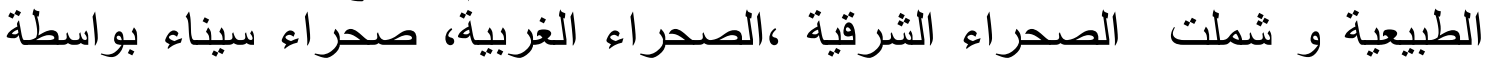

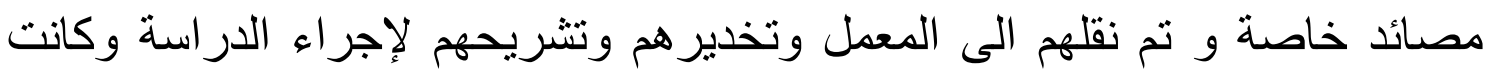

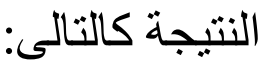
أولاً: الكبد يعتبر أكبر غدة في الجسم وهو يقع خلف الحجاب الحاجز فى الجزء الجهاء العلوى

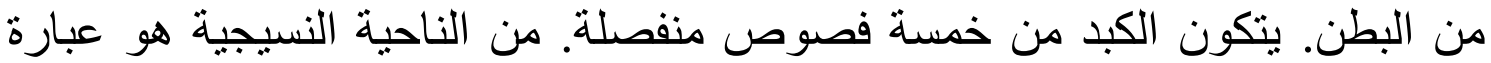

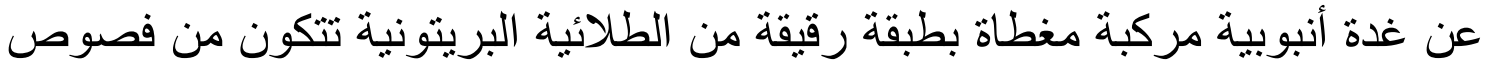

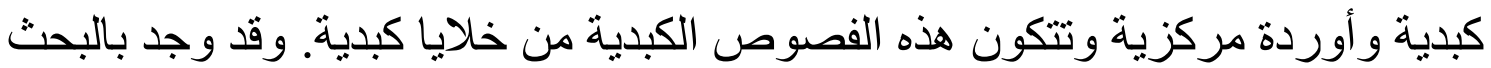

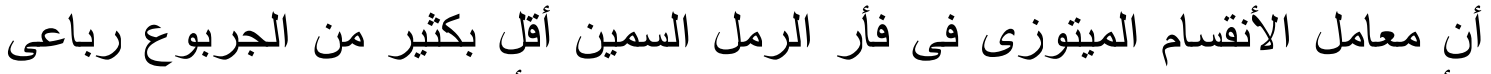

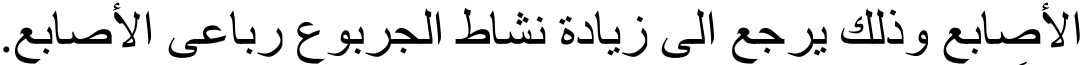

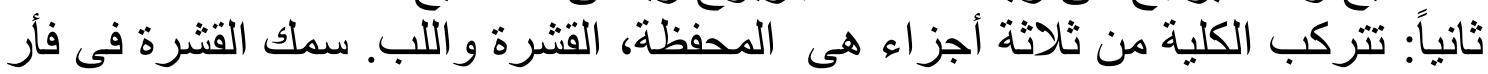

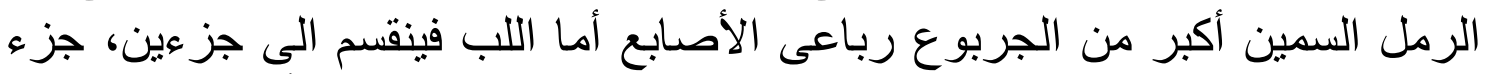

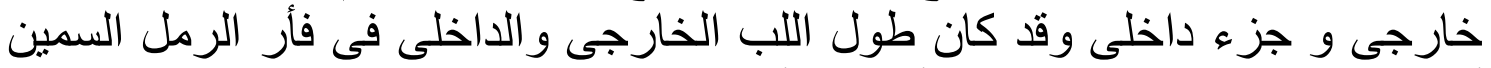

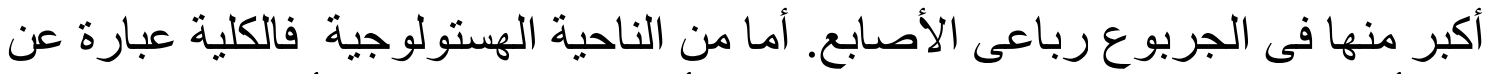

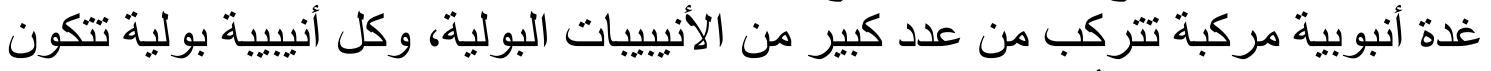

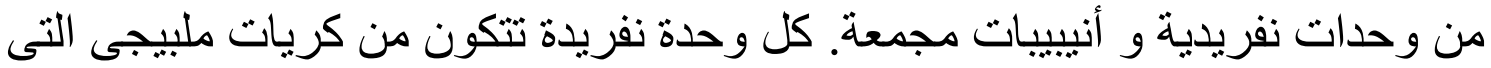

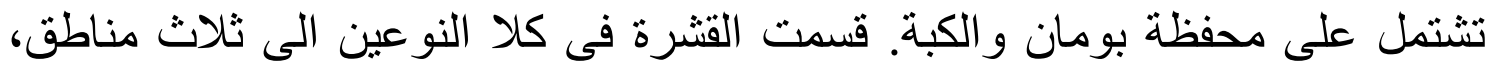

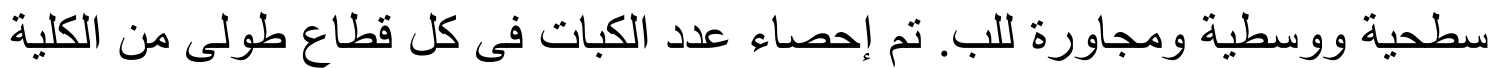

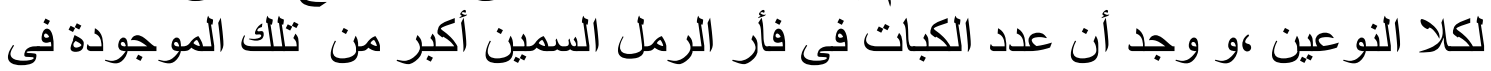

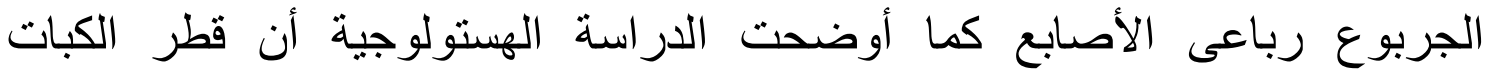

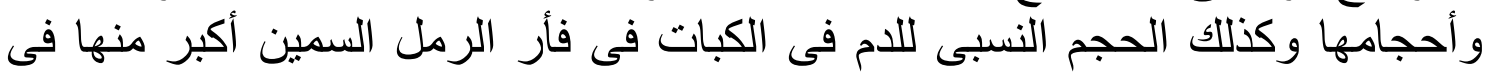

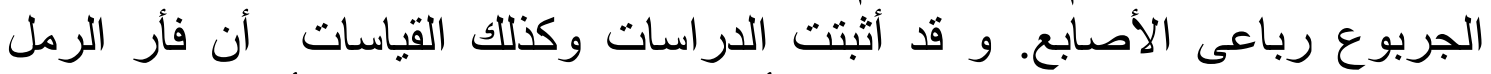

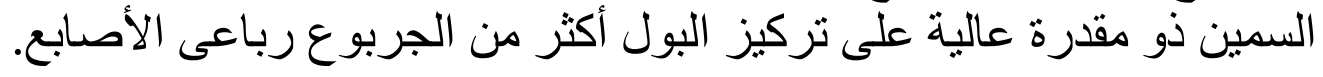

